\title{
PENGENDALIAN HAMA KUTU DAUN COKLAT PADA TANAMAN CABE MENGGGUNAKAN PESTISIDA ORGANIK EKSTRAK SERAI WANGI
}

\section{(The Control of Brown Leaves Insects' Pests (Toxoprera citricidus Kirk) on Chili (Capsicum annum L.) by Using Organic Pesticide Citronella Extract (Cymbopogon nardus L.))}

\section{FAHRUDDIN ARFIANTO}

\author{
Program Studi Agroteknologi Fakultas Pertanian dan Kehutanan \\ Universitas Muhammadiyah Palangkaraya \\ Jl. RTA Milono Km.1,5 Palangka Raya, Kalimantan Tengah 73111 \\ Email : fahruddin237@gmail.com
}

\begin{abstract}
Cultivation of chili is a farming activity promising an interesting profits and the market demand for the chili is high. Many chili farmers in controlling pests use chemical pesticides because it is considered more efficient and fast, actually the chemical pesticides do not kill insects' pests, but it creates a new form of defense for insects' pests. In another effort to find alternative pesticides are expected to be more lenient, then developing the manufacture of pesticides made from natural materials exist around the neighborhood, known by name "botanical pesticide" or "organic pesticide", because almost all the ingredients derived from plants.

The purpose of this study was to control brown leaves insects' pests on chilli by using citronella extract. The time in doing this study was as long as from October to November 2016. The study was done on Jl. Meranti IV Panarung Village, District Pahandut, the city of Palangka Raya.

From the results of the experiment of several concentration of extract of citronella $25 \mathrm{ml}, 50 \mathrm{ml}$ and $75 \mathrm{ml}$ and $100 \mathrm{ml}$ mixed with clean water for pest control of brown leaves insect on the chili, factually, by using concentration of citronella extract of $75 \mathrm{ml}$ and $100 \mathrm{ml}$ mixed with clean water, it can be reducing brown leaves insects' pest.
\end{abstract}

Keywords: brown leaves insects, citronella, citronella extract

\section{ABSTRAK}

Budidaya tanaman cabe merupakan kegiatan usaha tani yang menjanjikan keuntungan menarik karena permintaan pasar yang tinggi. Petani cabe mengendalian hama banyaknya menggunakan pestisida kimiawi karena dinilai efesien dan cepat. Pestisida kimiawi sebenarnya tidak membasmi serangga hama, tetapi menciptakan bentuk pertahanan baru bagi hama serangga. Upaya mencari alternatif pestisida yang diharapkan lebih lunak, maka berkembang pembuatan pestisida dari bahan-bahan alami yang ada di sekitar lingkungan yang dikenal dengan nama "pestisida nabati" atau "pestisida organik" karena hampir seluruh bahannya berasal dari tanaman (bahan-bahan organik).

Tujuan penelitian ini adalah untuk mengendalikan hama kutu daun cokelat pada tanaman cabe dengan menggunakan ekstrak serai wangi. Waktu yang dilakukan dalam penelitian ini selama 2 (dua) bulan pada OktoberNovember 2016 di lahan cabe Jl. Meranti IV Kelurahan Panarung, Kecamatan Pahandut, Kota Palangka Raya.

Hasil percobaan beberapa konsentrasi ekstrak serai wangi $25 \mathrm{ml}, 50 \mathrm{ml}$ dan $75 \mathrm{ml}$ dan ditambah $100 \mathrm{ml}$ air bersih untuk pengendalian hama kutu daun cokelat pada tanaman cabe, ternyata dengan konsentrasi ekstrak serai $75 \mathrm{ml}$ ditambah $100 \mathrm{ml}$ air bersih dapat mengurangi hama kutu daun cokelat pada tanaman cabe.

Kata kunci : kutu daun cokelat, serai wangi, ekstrak serai wangi

\section{PENDAHULUAN}

Budidaya tanaman cabe (Capsicum annuum L.) merupakan kegiatan usaha tani yang menjanjikan keuntungan menarik karena permintaan pasar yang tinggi. Cabe sudah hama itu berada. Dampaknya akhirnya terjadi pada metabolism tubuh hama dan juga pada tubuh tanaman. Insektisida tersebut selain diserap langsung oleh organ hama serangga, juga secara langsung diserap oleh organ tanaman baik lewat 
akar, batang maupun daun kemudian ditransportasikan mengikuti aliran cairan tubuh tanaman ke bagian tanaman lainnya.

Upaya mencari alternatif pestisida yang diharapkan mendukung ekosistem, maka berkembang pembuatan pestisida dari bahanbahan alami yang ada di sekitar lingkungan yang dikenal dengan nama "pestisida nabati" atau "pestisida organik" karena hampir seluruh bahannya berasal dari tanaman (bahan-bahan organik). Pestisida organik ini diharapkan sesuai untuk mengendalikan hama pada tanaman budidaya.

Teknologi pengendalian organisme penganggu tanaman (OPT) telah ditemukan antara lain varietas yang tahan, musuh alami dan beberapa jenis pestisida nabati yang aman bagi lingkungan dan konsumen. Teknologi alternatif yang aman sebagai pengganti pestisida kimiawi adalah pemanfaatan minyak atsiri sebagai bahan pembuatan pestisida organik. Salah satu tanaman yang mengandung minyak atsiri dan berpotensi sebagai bahan pembuatan pestisida organik adalah serai wangi (Cymbopogon nardus L.). Berdasarkan informasi hasil penelitian yang menunjukkan bahwa minyak atsiri yang dikandung oleh serai wangi berpotensi dan mampu menghambat perkembangan bahkan membunuh OPT. Hama pada tanaman cabe adalah salah satunya berupa hama kutu daun cokelat (Toxoprera citricidus Kirk.) yang diharapkan mampu dikendalikan dengan penyemprotan pestisida organik berbahan baku ekstrak tanaman serai wangi.

Berdasarkan upaya pengendalian hama pada tanaman cabe tersebut dan adanya potensi pemanfaatan tanaman sebagai bahan baku pestisida organik, maka dibutuhkan upaya yang tetap memiliki kemampuan yang baik dalam mengendalikan hama tetapi tetap juga menjaga lingkungan dengan baik. Oleh karena itu, tujuan penelitian ini adalah untuk mengendalikan hama kutu daun cokelat pada tanaman cabe dengan menggunakan ekstrak serai wangi.

\section{TINJAUAN PUSTAKA}

\section{Kutu Daun Coklat}

Kutu daun coklat adalah salah satu hama serangga dengan nama umum Myzus persicae Sulzer dengan klasifikasi sebagai berikut :

$\begin{array}{lll}\text { Kingdom } & : \text { Animalia } \\ \text { Filum } & : \text { Arthropoda } \\ \text { Kelas } & : \text { Insecta } \\ \text { Ordo } & : \text { Hemiptera } \\ \text { Subordo } & : \text { Sternorrhyncha } \\ \text { Superfamili } & : \text { Aphidoidea } \\ \text { Famili } & : \text { Aphididae } \\ \text { Genus } & : \text { Toxoprera } \\ \text { Spesies } & : \text { Toxoprera citricidus Kirk. }\end{array}$

Morfologi secara umum kutu daun berukuran kecil, antara 1-6 mm, tubuhnya lunak, berbentuk seperti buah pir, mobilitasnya rendah dan biasanya hidup secara berkoloni. Satu generasi kutu ini berlangsung selama 6 - 8 hari pada kondisi lingkungan dengan suhu sekitar $25^{\circ} \mathrm{C}$. Perbedaan antara $T$. citricidus dan $T$. aurantii terlihat pada pembuluh sayap bagian depan, dimana pada $T$. aurantii tidak bercabang, sedangkan pada $T$. citricidus bercabang. Kutu daun ini berbeda dengan serangga lainnya dalam berkembang biak, yaitu dengan melahirkan anaknya, dan termasuk serangga yang vivipar partenogenesis atau baik jantan maupun 
betinanya melahirkan anak, demikian juga imago kutu daun dapat bersayap maupun tidak bersayap. Kutu daun tidak menyebabkan kerusakan yang berarti pada tanaman, tetapi perannya sebagai vektor virus Tristeza jauh lebih berbahaya karena virus ini menyebabkan kerugian ekonomis yang tinggi. Pada saat tanaman sedang bertunas, perkembangbiakan kutu mencapai optimum (Direktorat Perlindungan Hortikultura, 2016).

\section{Tanaman Cabe}

Tanaman cabe menurut klasifikasi dalam tata nama (sistem tumbuhan) termasuk ke dalam :

$\begin{array}{ll}\text { Divisi } & \text { : Spermatophyta } \\ \text { Sub Divisi } & : \text { Angiospermae } \\ \text { Kelas } & : \text { Dicotyledoneae } \\ \text { Ordo } & : \text { Solanales } \\ \text { Famili } & : \text { Solanaceae } \\ \text { Genus } & : \text { Capsicum } \\ \text { Spesies } & : \text { Capsicum annum L. }\end{array}$

Cabai (cabe) atau lombok termasuk dalam suku terong-terongan (Solanaceae) dan merupakan tanaman yang mudah ditanam di dataran rendah ataupun di dataran tinggi. Tanaman cabe banyak mengandung vitamin $A$ dan vitamin $C$ serta mengandung minyak atsiri capsaicin, yang menyebabkan rasa pedas dan memberikan kehangatan panas bila digunakan untuk rempah rempah (bumbu dapur). Cabe dapat ditanam dengan mudah sehingga bisa dipakai untuk kebutuhan sehari-hari tanpa harus membelinya di pasar (Harpenas, 2010).

Menurut Samadi (1997), tanaman cabai merupakan salah satu komoditi hortikultura yang tergolong tanaman semusim. Tanaman cabai dibedakan dalam beberapa golongan dan tiap golongan memiliki berbagai jenis yaitu cabai merah besar, cabai merah keriting, cabai rawit dan paprika. Tanaman cabai merupakan tanaman yang berbentuk perdu, berdiri tegak dan bertajuk lebar. Tanaman ini juga memiliki banyak cabang dan setiap cabang akan muncul bunga yang pada akhirnya berkembang menjadi buah. Oleh karena itu cabai merah memiliki tajuk lebar, maka harus diberikan ajir sebagai penyangga agar tanaman hidup berdiri tegak.

Batang cabai tumbuh tegak, berwarna hijau tua dan berkayu. Pada ketinggian batang tertentu akan membentuk percabangan seperti huruf " $Y$ ". Batangnya berbentuk silindris, berukuran diameter kecil dengan tajuk daun lebar dan buah cabai yang lebat. Daun cabai berbentuk lonjong yang berukuran panjang $8-12 \mathrm{~cm}$, lebar $3-5 \mathrm{~cm}$ dan di bagian pangkal ujung daun meruncing. Pada permukaan daun bagian atas berwarna hijau tua, sedangkan dibagian bawah berwarna hijau muda. Panjang tangkai daunnya berkisar 2-4 $\mathrm{cm}$ yang melekat pada percabangan, sedangkan tulang daunnya berbentuk menyirip. Akar tanaman cabai tumbuh menyebar dalam tanah terutama akar cabang dan akar rambut. Bagian ujung akarnya hanya mampu menembus tanah sampai kedalaman $25-30 \mathrm{~cm}$. Oleh karena itu penggemburan tanah harus dilakukan supaya perkembangan akar sempurna.

Bunga cabai termasuk berkelamin ganda, karena pada satu bunga terdapat kepala sari dan kepala putik. Bunga cabai tersusun dari tangkai bunga yang berukuran panjang berkisar $1-2 \mathrm{~cm}$, kelopak bunga, mahkota bunga dan alat kelamin yang meliputi kepala sari dan kepala putik. Mahkota bunganya berwarna putih dan mengalami rontok bila buah mulai terbentuk. Jumlah mahkota bunga bervariasi antara 5-6 
kelopak bunga. Kepala putik barwarna kuning kehijauan dan tangkai kepala putiknya berwarna putih, panjangnya berkisar $0,5 \mathrm{~cm}$. Sedangkan kepala sari yang telah masak berwarna biru sampai ungu. Tangkai sarinya berwarna putih dengan panjang $0,5 \mathrm{~cm}$. Letak bunganya berada pada posisi menggantung, berukuran panjang antara 1-1,5 cm, lebarnya berkisar $0,5 \mathrm{~cm}$ dan warna bunganya menarik.

Buah cabai kebanyakan berbentuk memanjang yang berukuran panjang dan lebar sangat bervariasi, tergantung varietasnya. Buah cabai biasanya muncul dari percabangan atau ketiak daun dengan posisi buah menggantung. Buah cabai yang masih muda berwarna hijau, berangsur-angsur berubah menjadi merah menyala setelah buahnya tua.

\section{Tanaman Serai Wangi}

Tanaman serai wangi terutama pada batang dan daunnya mengandung zat-zat seperti geraniol, metil heptenon, terpen-terpen, terpenalkohol, asam-asam organik dan terutama sitronelal yang bisa dimanfaatkan sebagai penghalau nyamuk (Balittro, 2010).

Penelitian tentang manfaat tanaman serai wangi terus dilakukan dan dikembangkan seiring membangun kesadaran masyarakat untuk beralih natural. Khoirotunnisa (2008) menyatakan bahwa serai wangi adalah salah satu tanaman obat tradisional yang mengandung minyak atsiri yang dapat digunakan sebagai anti jamur utamanya terhadap jamur Malassezia furfur (jamur penyebab penyakit kulit yang disebut dengan "panu") secara invitro dan sebagai penghalau nyamuk Aedes. Klasifikasi tanaman serai wangi yaitu:

$\begin{array}{ll}\text { Divisi } & : \text { Spermatophyta } \\ \text { Sub Divisi } & : \text { Angiospermae } \\ \text { Kelas } & : \text { Monocotyledoneae } \\ \text { Ordo } & : \text { Poales } \\ \text { Famili } & : \text { Poaceae } \\ \text { Genus } & : \text { Cymbopogan } \\ \text { Spesies } & : \text { Cymbopogan nardus L. }\end{array}$

Tanaman serai wangi merupakan tanaman dengan habitus terna perennial. Serai wangi merupakan tanaman dari suku poaceae yang sering disebut deangan suku rumput-rumputan (Tora, 2013). Akar tanaman serai wangi memiliki akar yang besar, akarnya merupakan jenis akar serabut yang berimpang pendek (Arzani dan Riyanto, 1992).

Batang tanaman serai wangi bergerombol dan berumbi, serta lunak dan berongga. Isi batangnya merupakan pelepah umbi untuk pucuk dan berwarna putih kekuningan. Namun ada juga yang berwarna putih keunguan atau kemerahan. Selain itu, batang tanaman serai wangi juga bersifat kaku dan mudah patah. Batang tanaman ini tumbuh tegak lurus di atas tanah (Arzani dan Riyanto, 1992).

Daun tanaman serai wangi berwarna hijau dan tidak bertangkai. Daunnya kesat, panjang, runcing dan daun tanaman ini memiliki bentuk seperti pita yang makin ke ujung makin runcing dan berbau citrus ketika daunnya diremas. Daunnya juga memiliki tepi yang kasar dan tajam. Tulang daun tanaman serai tersusun sejajar. Letak daun pada batang tersebar. Panjang daunnya sekitar 50-100 cm, sedangkan lebarnya kira-kira $2 \mathrm{~cm}$. Daging daun tipis, serta pada permukaan dan bagian bawah daunnya berbulu halus (Arzani dan Riyanto, 1992). 
Keuntungan menggunakan ekstrak serai adalah: 1). merupakan bahan alami yang mudah terurai sehingga aman terhadap lingkungan dan produk pertanian, 2). memiliki harga yang relatif lebih murah dibanding dengan bahan pestisida sintetik, 3). aplikasi yang relatif mudah sehingga dapat dilakukan oleh setiap orang. Fungsi atau manfaat yang diperoleh dari penggunaan pestisida organik serai (buatan sendiri) berkat adanya kandungan senyawa aktif dari keseluruhan bagian tanaman serai dalam bentuk ekstrak/minyak atsiri. Zat-zat atau senyawa aktif terdiri dari dipentena, farnesol, geraniol, mirsena, metal heptenol, sitronella, nerol dan sitral. Kandungan senyawa aktif tanaman serai dapat mengendalikan hama tanaman termasuk: kepik cokelat, kutu tanaman dan beberapa serangga Tribolium sp, Sitophilus sp, Callosobruchus sp, Nematoda (Meloidogyne sp), dan jamur (Pseudomonas sp).

\section{METODOLOGI}

\section{Waktu dan Tempat}

Penelitian ini dilaksanakan selama 2 (dua) bulan pada bulan Oktober-November 2016. Aplikasi pestisida organik pada atanaman cabe dilakukan selama 3 (tiga) minggu mulai tanggal 16 Oktober 2016 sampai tanggal 7 November 2016. Penelitian ini dilaksanakan di lahan tanaman cabe yang berlokasi di Jl. Meranti IV Kelurahan Panarung, Kecamatan Pahandut, Kota Palangka Raya.

\section{Alat dan Bahan}

Alat yang di gunakan untuk pembuatan pestisida organik adalah pisau, penumbuk (mortar), panci ukuran $3 \mathrm{I}$, kompor, jerigen air ukuran 2,5 I, timbangan analitik, gelas ukur, saringan, handsprayer, kamera, alat tulis, kalkulator, dan komputer. Bahan percobaan adalah tanaman cabe dan hama kutu daun cokelat. Sedangkan bahan yang diperlukan untuk pembuatan pestisida organik adalah batang serai wangi dan air bersih,

\section{Pembuatan Pestisida Organik}

Pembuatan pestisida organik berbahan baku batang serai wangi adalah dengan langkah sebagai berikut:

a. Siapkan batang serai wangi segar yang sudah dibersihkan dari daun, kemudian ditimbang sebanyak $100 \mathrm{~g}$.

b. Batang serai wangi segar lalu dibasuh menggunakan air mengalir dengan tujuan untuk membersihkan kotoran yang ada di batang serai wangi tersebut.

c. Batang serai wangi yang segar dan bersih tersebut kemudian ditumbuk.

d. Siapkan panci kemudian diisi air bersih sebanyak $2.000 \mathrm{ml}$ dan dimasukkan batang serai wangi yang segar, bersih dan sudah ditumbuk tersebut.

e. Rebus serai wangi tersebut hingga mendidih (40 menit), dan dalam proses perebusan dilakukan aduk-aduk serai wangi tersebut sampai serai wangi mengeluarkan minyak atsirinya.

f. Dinginkan serai wangi tersebut lalu dimasukkan air rebusan serai wangi beserta serainya ke dalam jerigen air (Gambar 1).

g. Dilakukan inkubasi air rebusan batang serai wangi tersebut selama 24 jam sebagai ekstrak serai wangi dan disebut dengan pestisida organik (Gambar 1). 


\section{Aplikasi Pestisida Organik}

Pengaplikasian pestisida organik ekstrak serai wangi untuk mengendalikan hama kutu daun cokelat pada tanaman cabe dilakukan sebagai berikut:

a. Mengambil ekstrak serai wangi sebagai pestisida organik dengan cara larutan ekstrak disaring dari jerigen dan diukur menggunakan gelas ukur.

b. Membuat sebanyak 3 (tiga) jenis konsentrasi larutan pestisida organik, yaitu:

$$
\begin{aligned}
\mathrm{PO}_{1}= & \text { konsentrasi } 25 \mathrm{ml} \text { ekstrak serai } \\
& \text { wangi ditambah air bersih } 100 \mathrm{ml} . \\
\mathrm{PO}_{2}= & \text { konsentrasi } 50 \mathrm{ml} \text { ekstrak serai } \\
& \text { wangi ditambah air bersih } 100 \mathrm{ml} . \\
\mathrm{PO}_{3}= & \text { konsentrasi } 75 \mathrm{ml} \text { ekstrak serai } \\
& \text { wangi ditambah air bersih } 100 \mathrm{ml} .
\end{aligned}
$$

c. Menyemprotkan pestisida organik ekstrak serai wangi seminggu sekali sesuai konsentrasi masing-masing selama 3 (tiga) minggu berturut-turut menggunakan hand sprayer yang dilakukan pada pagi hari pukul 08.00 WIB.

\section{HASIL DAN PEMBAHASAN}

\section{Hasil Pengamatan}

Hasil pengamatan aplikasi penyemprotan pestisida organik ekstrak serai wangi dalam mengendalikan hama kutu daun cokelat pada tanaman cabe di setiap minggu penyemprotan disajikan pada Tabel 1, 2 dan 3.

\section{Pembahasan}

Berdasarkan hasil pengamatan penelitian pada Tabel 1 menunjukkan bahwa pada minggu pertama dengan penyemprotan pestisida organik ekstrak serai perlakuan $\mathrm{PO}_{1}(25 \mathrm{ml}$ ditambah air bersih $100 \mathrm{ml}$ ) ternyata belum menunjukkan pengaruh dan kondisi hama kutu daun cokelat masih ada pada tanaman cabe. Hal ini membuktikan bahwa konsentrasi ekstrak serai wangi yang diberikan belum berpengaruh terhadap hama kutu daun cokelat yang menempel pada daun tanaman cabe.

Penyemprotan ekstrak serai wangi di minggu kedua, berdasarkan Tabel 2, juga menunjukkan bahwa penyemprotan pestisida organik ekstrak serai wangi perlakuan $\mathrm{PO}_{2}(50 \mathrm{ml}$ ditambah air bersih $100 \mathrm{ml}$ ) ternyata sudah menunjukkan adanya pengaruh dan kondisi hama kutu daun cokelat sudah sedikit berkurang pada tanaman cabe. Hal ini membuktikan bahwa konsentrasi ekstrak serai 50 mulai efektif berpengaruh terhadap hama kutu daun cokelat yang menempel pada daun tetapi belum maksimal menghilangkan kutu daun cokelat secara keseluruhan di tanaman cabe.

Pengendalian minggu ketiga pada Tabel 3 , nampaknya memperlihatkan bahwa penyemprotan pestisida organik ekstrak serai wangi perlakuan $\mathrm{PO}_{3}(75 \mathrm{ml}$ ditambah air bersih $100 \mathrm{ml}$ ) ternyata memberikan pengaruh sangat baik dan lebih efektif mengendalikan hama karena kondisi kutu daun cokelat cukup banyak berkurang pada tanaman cabe meskipun belum mampu menghilangkan kutu daun cokelat secara keseluruhan yang menempel pada daun tanaman cabe (Gambar 2 dan 3). Hal ini membuktikan bahwa konsentrasi ekstrak serai $75 \mathrm{ml}$ ditambah air bersih $100 \mathrm{ml}$ yang disemprotkan pada minggu ketiga ternyata lebih efektif mengendalikan karena berpengaruh terhadap hama kutu daun cokelat pada tanaman cabe. 
Tabel 1. Kondisi pengendalian hama kutu daun cokelat pada tanaman cabe akibat penyemprotan pestisida organik ekstrak serai wangi pada minggu pertama

\begin{tabular}{ccc}
\hline Perlakuan Konsentrasi & \multicolumn{2}{c}{ Kondisi Pengendalian Minggu ke-1 } \\
\cline { 2 - 3 } Ekstrak Serai Wangi & Pengaruh & Serangan Hama \\
\hline $\mathrm{PO}_{1}$ & tidak ada pengaruh & kutu daun cokelat \\
$(25 \mathrm{ml}$ ekstrak $+100 \mathrm{ml}$ air $)$ & & masih ada \\
\hline
\end{tabular}

Tabel 2. Kondisi pengendalian hama kutu daun cokelat pada tanaman cabe akibat penyemprotan pestisida organik ekstrak serai wangi pada minggu kedua

\begin{tabular}{lcc}
\hline Perlakuan Konsentrasi & \multicolumn{2}{c}{ Kondisi Pengendalian Minggu ke-2 } \\
\cline { 2 - 3 } Ekstrak Serai Wangi & Pengaruh & Serangan Hama \\
\hline $\mathrm{PO}_{2}$ & ada pengaruh & kutu daun cokelat \\
$(50 \mathrm{ml}$ ekstrak $+100 \mathrm{ml}$ air $)$ & & sedikit berkurang \\
\hline
\end{tabular}

Tabel 3. Kondisi pengendalian hama kutu daun cokelat pada tanaman cabe akibat penyemprotan pestisida organik ekstrak serai wangi pada minggu ketiga

\begin{tabular}{ccc}
\hline Perlakuan Konsentrasi & \multicolumn{2}{c}{ Kondisi Pengendalian Minggu ke-3 } \\
\cline { 2 - 3 } Ekstrak Serai Wangi & Pengaruh & Serangan Hama \\
\hline $\mathrm{PO}_{3}$ & ada pengaruh & kutu daun cokelat \\
$(75 \mathrm{ml}$ ekstrak $+100 \mathrm{ml}$ air $)$ & & cukup banyak berkurang \\
\hline
\end{tabular}

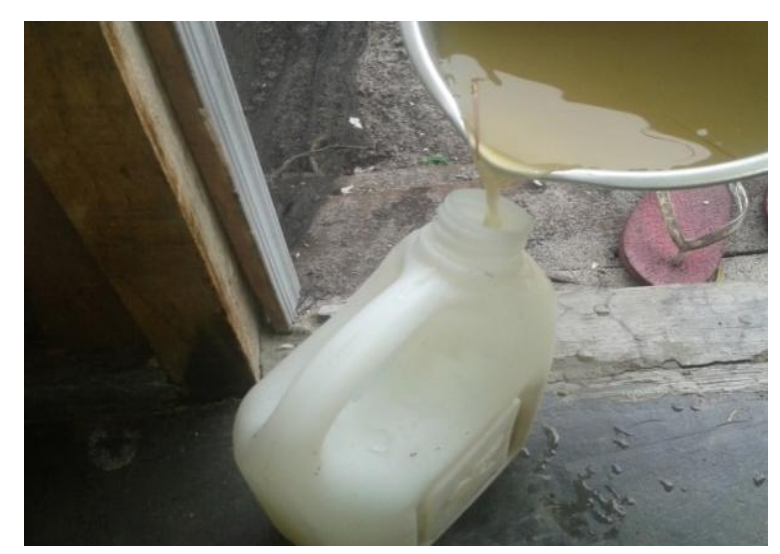

Gambar 1. Ekstrak serai wangi selesai diproses yang dituang dimasukkan ke dalam jerigen

Berdasarkan hasil percobaan beberapa konsentrasi ekstrak serai wangi mulai $25 \mathrm{ml}, 50$ $\mathrm{ml}$ dan $75 \mathrm{ml}$ dan dicampur air bersih $100 \mathrm{ml}$ untuk pengendalian hama kutu daun cokelat pada tanaman yang diberikan cabe selama 3 minggu, ternyata dengan konsentrasi ekstrak serai wangi $75 \mathrm{ml}$ ditambah air bersih $100 \mathrm{ml}\left(\mathrm{PO}_{3}\right)$ dapat mengurangi hama kutu daun cokelat lebih banyak. Hal ini karena dengan konsentrasi $\mathrm{PO}_{3}$ tersebut menunjukkan bahwa kandungan minyak atsiri yang dikandungnya lebih banyak sehingga lebih efektif mengendalikan. Hal ini sesuai dengan yang dijelaskan Rizal (2009) bahwa salah satu minyak atsiri dengan nama dagang Java Citronella Oil yang dapat digunakan sebagai insektisida, fungisida, bakterisida, moluskasida 


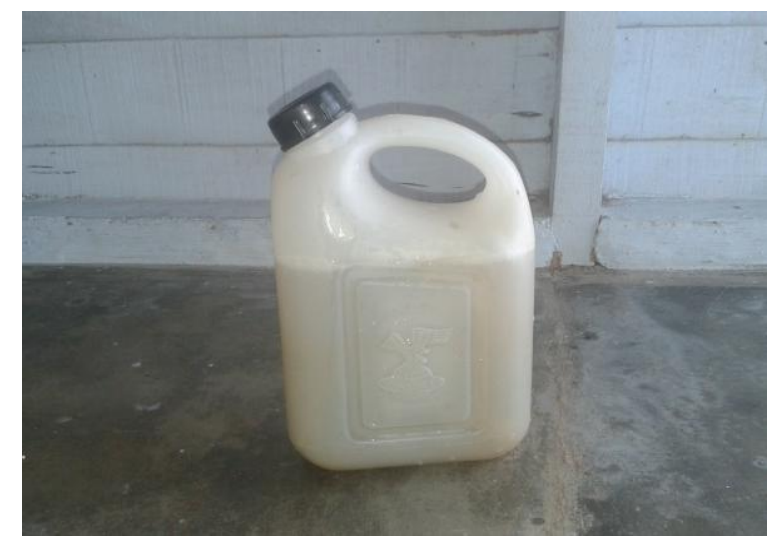

Gambar 2. Ekstrak serai wangi yang diinkubasi di jerigen siap disemprotkan sebagai pestisida organik

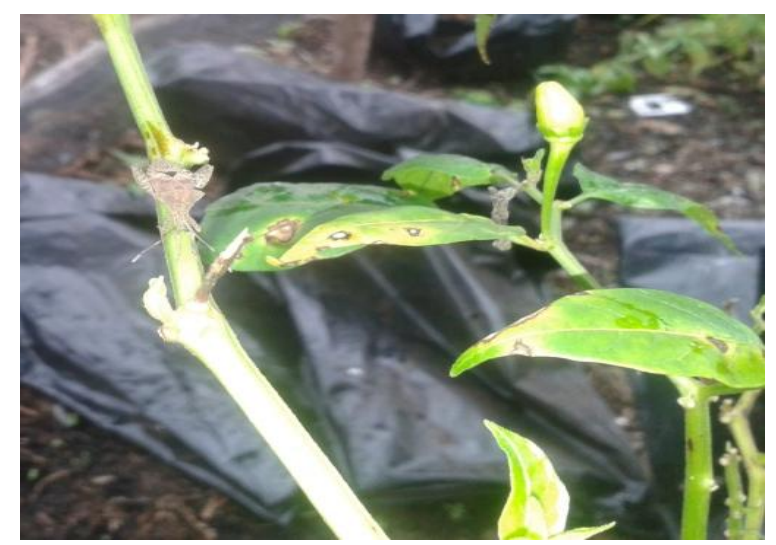

Gambar 7. Hama kutu daun cokelat pada tanaman cabai

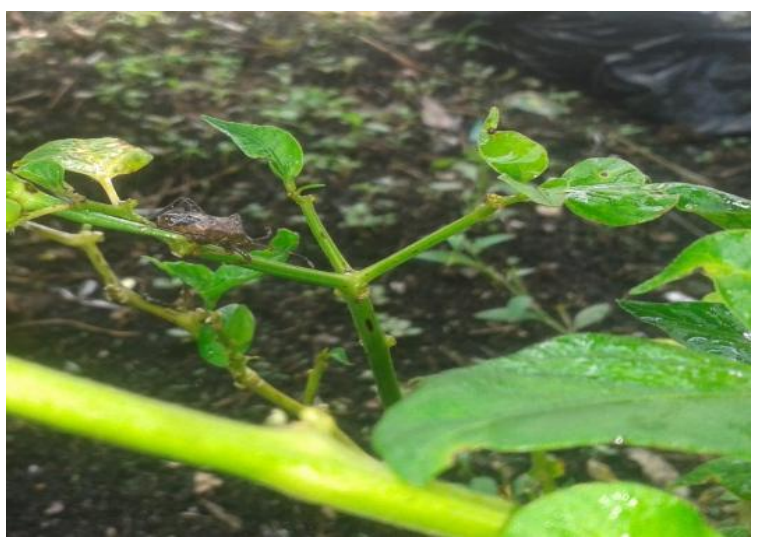

Gambar 8. Kondisi hama kutu daun cokelat yang sudah disemprotkan pestisida organik dari ekstrak serai wangi 
dan bersifat penolak (reppelent) hama ternyata adalah berasal dari tanaman serai wangi. Kondisi ini juga sependapat dengan pendapat sebelumnya menurut Hubagyo dan Losowinarto (1995) bahwa ekstrak serai wangi mengandung minyak atsiri senyawa aldehid yang diduga mempunyai sifat repellent terhadap serangga.

Efektifnya ekstrak serai wangi menjadi pestisida organik ternyata dikarenakan ekstrak serai wangi memiliki kandungan senyawa citronella yang tidak disukai oleh hama serangga, termasuk hama kutu daun cokelat pada tanaman cabe. Citronella merupakan minyak esensial bersifat insect repellent yang didapat dari daun dan batang spesies Cymbopogan. Kandungan serai wangi menurut Setiawati dkk (2010) yaitu terdapat citronella $(35,97 \%)$, nerol $(17,28 \%)$, sitronelol $(10,03 \%)$, geranyle acetat $(4,44 \%)$, elemol $(4,38 \%)$, limonene $(3,98 \%)$ dan citronnellyle acetate $(3,51 \%)$. Senyawa citronella mempunyai sifat sebegai racun dehidrasi bagi hama serangga. Racun tersebut merupakan racun kontak yang dapat mengakibatkan kematian karena serangga akan mengalami kekurangan cairan. Mekanismenya, yaitu zat citronella yang terkandung berfungsi sebagai racun kontak bagi serangga, selain itu bau dari oleum citronella juga tidak disukai oleh indera penciuman hama serangga (Gambar 3). Oleh sebab itulah serangga jenis kutu daun cokelat tidak menyukai bau dari ekstrak serai wangi.

\section{KESIMPULAN DAN SARAN}

\section{Kesimpulan}

Hasil penelitian ini menghasilkan kesimpulan, bahwa :

a. Aplikasi penyemprotan pestisida organik ekstrak serai wangi konsentrasi $25-75 \mathrm{ml}$ ditambah air bersih $100 \mathrm{ml}$ berpengaruh mulai minggu kedua terhadap hama kutu daun cokelat pada tanaman cabe.

b. Penyemprotan pestisida organik ekstrak serai wangi konsentrasi $75 \mathrm{ml}$ ditambah air bersih $100 \mathrm{ml}$ lebih berpengaruh dan efektif pada minggu ketiga terhadap pengendalian hama kutu daun cokelat pada tanaman cabe.

\section{Saran}

Hasil penelitian ini sebaiknya dilanjutkan dalam bentuk penelitian lanjutan yang bisa menemukan berapa kosentrasi, dosis dan waktu pemberian yang tepat untuk pengendalian hama kutu daun cokelat pada tanaman cabe sehingga efektif dan maksimal.

\section{DAFTAR PUSTAKA}

Apriyantono. 2009. Lampiran Keputusan Menteri Pertanian No. 2084/ Kpts/SR.120/5/2009. http://www.scribd.com/doc /48769668/ budiya-cabepdf diakses tanggal 21 Maret 2011.

Direktoral Perlindungan Hortikultura Kementerian Pertanian, 2016. http://ditlin.hortikultura.pertanian.go.id/index .php?option=com_content\&view=article\&id $=66 \&$ ltemid $=184$ diakses tanggal 1 Desember 2016

Harpenas, A dan R. Dermawan. 2010. Budidaya Cabai Unggul (Cabai Besar, Cabai Keriting, Cabai Rawit, dan Paprika). Penebar Swadaya, Jakarta, $108 \mathrm{hlm}$. 
Litbang. 2015. Pemanfaatan Minyak Sereh Wangi Untuk Pengendalian Hama Pada Tanaman Hortikultura.

http://balitbu.litbang.pertanian.go.id/ind/inde x.php/component/content/article/16penelitia npengkajian2/349-pemanfaatan-minyaksereh-wangi-untuk-pengendalian-

hamapada-tanaman-hortikultura. diakses pada tanggal 18 Oktober 2016.

Musnamar, E.I. 2003. Pupuk Organik (Cair, Padat, Pembuatan da Aplikasi). Penebar Swadaya. Bogor. $71 \mathrm{hlm}$.

Rizal., Molide. 2009. Pemanfaatan Tanaman Atsiri Sebagai Pestisida Nabati. Balai Penelitian Tanaman Obat dan Aromatik. Bogor

Setiawati, R. Murtiningsih, N. Gunaeni, dan T. Rubiati. 2008. Tumbuhan Bahan Pestisida Nabati dan Cara Pembuatannya untuk Pengendalian Organisme Pengganggu Tumbuhan (OPT). Balai Penelitian Tanaman Sayuran. 